\title{
Communicative Strategies and Misunderstandings. Discourse Analysis of the Russian North Caucasus Case
}

\author{
Dmitrii Gavra $^{1} \&$ Svetlana Glazkova ${ }^{1}$ \\ ${ }^{1}$ Saint-Petersburg State University, Russian Federation \\ Correspondence: Dmitrii Gavra, Vassilievsky Ostrov, 1 Line, 26, Saint-Petersburg, 199004, Russian Federation. \\ E-mail: dgavra@mail.ru
}

Received: March 4, 2015 Accepted: May 5, 2015 Online Published: July 30, 2015

doi:10.5539/ass.v11n19p237 URL: http://dx.doi.org/10.5539/ass.v11n19p237

\begin{abstract}
The paper proposes the critical discourse analysis as the method for the reconstruction of communication on the social problem. This approach provides explanation why the particular informational campaign was ineffective and the how the communication strategy has to be reconsidered. In presented study three types of social actors are defined: the authorities, the mass media and the citizens. These actors interpret the situation, produce discourse and make the influence on the formation of a social conception of problematic situation. The empirical case is media reflection of the situation in the North Caucasus region of Russia in 2011-2012. For the analysis of three discourses two corpuses of texts thematically connected to the problem were chosen: news articles and Internet posts during two chronological periods - August-November 2011 and April-June 2012.

Analysis of mass media texts, official statements and comments on these communications by Internet audience enabled to draw out conclusions on the process of interpretation of social problem: the priority of the power institutions (institutional) discourse in the determination of social problem; the absence of interaction between the discourses. The disconnection between three discourses on the one social problem can be viewed as a symptom of ineffective communication strategy of the federal authorities. Empirical study has shown the way the communication strategy towards the social problem to be corrected in order to become more effective.
\end{abstract}

Keywords: communication strategy, social issue/problem, critical discourse analysis, interdiscursivity, discourse, intersection of discourses, North Caucasus, governmental communication, media, public discourse

\section{Introduction}

Today the information and communication management, political communication and aspects of influence in communication are the questions of high priority. Fast development of informational technologies increases these tendencies. The history of $20^{\text {th }}$ century proved the determinant role of mass communications in the periods of social transition. So, the technological aspects of communicative influence as aspects of the distribution of power and authority in the system of mass communication attract attention of researchers especially in the situations of economic, financial, political or social instability. Detailed analysis of power relationships in communication becomes more important both for the political and business actors.

To some extend the analytical interest passes from hermeneutical questions toward questions of communication. The problems of comprehension and interpretation of the text per se give place to the problems of text's functioning in the process of communication. The text is viewed as a phenomenon producing a communicative event and becoming itself the consequence of such event. So, we have the most popular subject of social research-the discourse. The methods of discourse analysis are now used in the different spheres of social studies (Titcher et al., 2000; Bednarek \& Caple, 2012; Bednarek \& Caple, 2014, pp. 135-158). In our case we consider social problem from the perspective of the critical discourse analysis.

We have not only the theoretical interest in this task but also a practical reason. The application of this method can help to evaluate the current communication strategy in such kind of relationships, that impact on different spheres of the social life. Communication strategy of the actors who dominate in the social-political relationship (the power institutions, for instance) is able to contain (explicitly or implicitly) several attitudes that determine the social reality. But if the whole strategy is based on the wrong principles it becomes ineffective.

The research task in the critical discourse analysis perspective is to discover relationships between authority, 
domination and control; to find out how such relationships are manifested in discourse with or without intention (Jorgensen \& Phillips, 2002). The vast amount of studies is devoted to the finding of ideological influence in the different types of discourses. Pierre Bourdieu (Champagne, 1990) has shown that the political dominance is based mainly on the symbolical mechanisms; when the most important act is hidden and tends to thrust the systems of classifications of the social world. From the other side, P. Bourdieu (Bourdieu, 1980) has remarked, that the ideological analysis in narrow sense, as understanding of legitimated discourses, without analysis of correspondent mechanisms tends to become no more than additional investment to the effectiveness of these ideologies. According to Bourdieu it happens in any internal (semiological) analysis of political, school-educational, religious or aesthetical ideologies.

The study of ideology needs to be conducted in two dimensions: the proclaimed form and the latent form of ideological content. Hermeneutical analysis is to be combined with so called "techniques of objectivities". The study of text forms includes investigations of socio-historical context and formal discourse analysis, as M. M. Nazarov (1991) has pointed. From our point of view, in such case the most accurate results could be drawn from the critical discourse analysis. In our understanding the critical discourse analysis is viewed as an academic movement, "a way of doing discourse analysis from a critical perspective, which often focuses on theoretical concepts such as power, ideology and domination" (Baker et al., 2008, pp. 273-306).

It has been noted (Baker et al., 2008, pp. 273-306) that critical discourse analysis requires interdisciplinary approach for the discovery the ideological schemes aimed on the objectivation, corresponding mechanisms and techniques; it also requires diachronic view on processes in the particular sphere of social interaction. Due to this perspective researcher is able to reconstruct the role of discourse in formation and transmission of the knowledge, also in organization of the social institutions or in practicing authority in different spheres of society (Van Dijk, 1981, pp. 215-244).

\section{Theoretical Considerations}

\subsection{Discourse and Social Problem}

Critical discourse analysis produces special possibilities for the researcher-it helps to detect the meaning of social problem and to define its characteristics (Glazkova, 2011, pp. 205-212). Even in cases when the problematic situation exists but is not evident for social actors involved. In sociology (Ivanov, 2008, pp. 7-19) (Posel, 2008, pp. 111-127) social problem is defined as the objective existing contradiction between the necessity of some social action or process and the shortage of conditions for their realization.

Social actors involved in the particular problematic situation interpret it and the way of interpretation affects their behavior and interaction with problematic reality. Discursive practices contain rich information on mentioned implicit structural parameters of social problem: how actors involved detect a problem, interpret and evaluate it (Berezin \& Tarasov, 1990). In some cases interacting social actors do not want/or can't admit the existence of social problem. It means that the problematic situation can exist objectively but at the same time is hidden for some actors and even for the mass public (De Beaugrande, 2008, pp. 17-30). In such cases influential actors-political or economic-can act to minimize the possibilities for the other actors to realize the problematic character of the situation they are involved in. This is, actually, an ideological task per se.

So, we propose the critical discourse analysis as the method of reconstruction the social problem. As the case the process of integration of the North Caucasus region into the Russian present-day reality is selected. This is the important part of political agenda for the Russian government, but the information campaigns often are not effective. Our task is to discover probable negative factors that upset the normal functioning of the public discourse on the mentioned social issue.

The public discussion on integration of the republics of North Caucasus in the Russian present-day social reality gives an example of how this process of detecting, interpretation and evaluation of the social problem in mass consciousness is realized. The long period of political instability in several republics of the North Caucasus Region and corresponding social and economic problems has produced a number of negative tendencies in development of democracy, human rights and ethnic relations in this region and other regions of the Russia Federation.

Analysis consisted of several stages. We had to:

- Define the subjects of the social interaction and the problematic aspects of this interaction;

- Define problematic nodes, actors discuss during such interaction;

- Detect the situations of communication when social interaction of such kind takes place; 
- Analyze the corpus of texts created in the process of communication and the corresponding social and political context.

\subsection{Theoretical Considerations on Discourse and Mass Media}

For our study we defined three types of social actors producing discourse and influencing social conceptualization of problematic situation: the authorities (federal government), the mass media and the citizens (public sector). All of them produce the discourse on the North Caucasus. T. A. Van Dijk (2005) insists on the priority to study the symbolic elites' discourse. Politicians, journalists, scientists, teachers, writers play the special role in reproduction of the dominant knowledge and ideology in society. T. A. Van Dijk (1993) has pointed out that prejudices are not innate, but socially acquired, and because such acquisition is predominantly discursive, the public discourses of the symbolic elites are the primary source of shared ethnic prejudices and ideologies. In our case the discourse of symbolic elites is represented by the mass media discourse and the institutional discourse of authorities.

Discourse of mass media plays important role in the formation of social attitudes. It is interesting to see how the mass media discourse interacts with the institutional discourse, where the authorities determine the frame for interpretation of current events and set the priorities of the events (Van Dijk, 1985; 1988, pp. 1-30). This situation is typical for the Russian present-day reality.

The institutional discourse giver the desired by the power institutions frame of interpretation of social reality; it defines the presence the social problem, gives it a name, and proposes an official interpretation of the problem. In many cases official institutional discourse gives orientation how power institutions want this problem to be solved what should be desired dynamics of such solving.

Mass media cooperate with this discourse either by delivering the details of governmental version or on the contrary by producing the conception about failed experience of the problem solution (Reyes, 2011, pp. 781-807; Yasaveev, 2004). In case of the second variant power institutions give answer in the media format. In "not so obvious" cases the authority discourse does not react on the "irritating" information.

The public discourse of citizens is their communicative reaction on the events in the public sphere; it reflects a comprehension of social problem in different social groups. The reaction of public discourse on the social problem demonstrates the frames of social problem comprehension and interpretation by social groups involved in or communicating about particular problem.

Considering three discourses on the North Caucasus-discourse of authority (institutional discourse), news discourse (mass media) and "civic/citizens" discourse-researcher should pay attention to the phenomenon of interdiscursivity appearing in the communicative dispositions of such kind.

As it was noted (Baker et al., 2008) interdiscursivity means that in situations of complex multy-subject social interaction discourses are also interacting and are connected to each other in different configurations. Candlin and Maley (1997) in their study of the discourse of mediators, define_interdiscursivity as meta-communication concept: 'the use of elements in one discourse and social practice which carry institutional and social meanings from other discourses and social practices'.

We consider interdiscursivity as a phenomenon of pragmatic sphere. The actors producing one type of discourse use the elements of another type (such as topics and subtopics) in order to achieve the special goals: to establish communication with other actors; to discuss the issue "in terms of another discourse" (gaining communicate advantages using the opposing discourse elements). Interdiscursivity can be traced in synchronic and diachronic dimensions. The diachronic version of interdiscursivity takes place in the special type of communicative situations which we can find in mass media discourse-the discussion by correspondence: inside the opposition politically marked or unmarked; between the authorities and an opposition; between the authorities and mass media.

The degree of interdiscursivity can be estimated by the number of common topics and subtopics in the different discourses. This degree of interdiscursivity characterizes the intensity of the processes of communication as the reaction on the problematic situation or on the process of the solving a problem. It also can evidence on agreement or disagreement between social actors in their interpretation of the social problem and social problematization in general.

Thus, the task of our empirical study is to determine such interdiscursivity between three types of discourses on the North Caucasus case communicated by three types of the social actors: the federal authorities of the Russian Federation, the mass media and the citizens. 


\section{Methods}

As we have pointed before our approach is based on the critical discourse analysis. The method is based on the comparison of the data containing in the three corpuses of texts produced by the types of social actors. Each corpus is compared with every other with and the situation context is taken into consideration. Fixing of what was said or even unsaid by the social actors in the same problematic situation provides us the frames of actors' interpretation of the social problem.

The social problem we focus on is the integration of the republics of the North Caucasus in the contemporary Russian social reality.

Three discourses are under the consideration: the mass media discourse, the federal authorities' discourse and the people/citizens discourse.

For the analysis of three discourses two corpuses of texts thematically connected to the problem were selected. Each texts corpus contains the news articles published in the newspapers and Internet posts. Text were collected for the two chronological periods: August-November 2011 and April-June 2012.

During the first period as the central event we follow the meeting of the Russian Government Committee on Socioeconomic Development of the North-Caucasus Federal Region which was led by the Prime Minister (at that time, now President) Vladimir Putin on August, 32011 in the city of Kislovodsk. This case provides bright example of the interdiscursivity of three mentioned above discourses. The biggest part of the texts is presented by the news articles from this region. The news sources are represented by the Internet media or Internet versions of the print media.

The reason to include the second chronological period was to analyse in addition to calm peaceful case the case connected with insurgent and federal armed forces military activity in some parts of the North Caucasus region. The sources of the texts are federal and regional mass media located in the Internet.

The total amount of texts we determine as belonging mass media discourse-116 units. These texts are produced by the journalists both in informational and analytical genres.

The discourse of the federal authorities is also presented in mass media. These texts contain official statements or direct speech of the governmental speakers, quotations from official documents presented in the media discourse. Total amount of texts compose the authorities' discourse-35 units.

The civic discourse on the North Caucasus region is taken from thematic web sites, comments on web media sites and discussions in social networks, including Facebook and the most popular Russian social network VKontakte. The civic discourse is represented in two subtypes: politically marked and politically unmarked. The character of these two subtypes is different, but here we do not comment this distinction. The first subtype is represented by the materials of web sites of political opposition; for example: "Kasparov.ru" and "vnssr.my1.ru"-The Renaissance of National-Social Justice Party. The second subtype is represented in numerous comments on the current news from the North Caucasus on the news web sites. Total amount of the commentary lines located on the news web sites-92 units.

The Corpus of Media Sources was as following:

- Russian Information Agency "News" ("Novosti”)-www. ria.ru

- Vedomosti-www.vedomosti ru

- Expert.ru-www.expert.ru

- Newsru.com-www.newsru.com

- Newsland.ru-www.newsland.com/news/

- Yuga.ru (South Region Information Portal-http://www.yuga.ru/news/

- KavkazWeb.net-www.kavkazweb.net

- Russian Information Agency Dagestan-www.riadagestan .com

- Infox.ru-www.infox.ru

- vnssr.my1.ru-www .vnssr.my1. ru

- Kasparov.ru-www.kasparov.ru 


\section{Results and Discussion}

\subsection{The Mass Media Discourse}

The pragmatic context of the news discourse proposes recognition of some fact or event occurrence and concentration on the details of the fact/event. The discourse of news from the North Caucasus is monotonous by topics/subjects and contents. Analysis has shown that the vast majority (more than $80 \%$ ) of news about the region is positive. This news flow is represented by the reports on achievements of local and regional authorities solving routine problems social and economic problems of the territory. The negative news contains information about acts of terrorism, armed attacks on civil servants, victims, counter-terrorists operations.

Another topic often appear in mass media discourse is international relations and attacks on this cause in the North Caucasus Region and in other regions of the Russia Federation. In the second chronological period under analysis such reports are especially numerous. During June 2012 the Web Portal of the South Region reports on 9 armed incidents in the North Caucasus. The Web Portal Gazeta.ru informs on 11 incidents on this month.

Lexical analysis of the news evidences on military character of all these incidents. All the incidents are nominated as: "terroristic acts", "combat", "fire contact", "special operation", "liquidation", "and armed resistance".

Participants were nominated as: "fighters", "terrorists", "unidentified persons", "criminals", "gang groups", "illegal armed formations", "and separatists".

Victims were named as: "policemen", "service-men", "folk-doctor", and "person".

So, this lexical material proves the frame of conflict as the conflict between terrorists and the authority, and this framing separates the conflict from the other parts of society. At the same time it produces in mass consciousness the strong connotation of this territory with real and potential threat.

Even if we take the news line on the later period we can see the regularity of this kind of negative news. It can be illustrated by the news line from the web portal Yuga.ru (the Web Portal of the South Region). So we can choose for the analysis of mass media discourse any period of time:

“6.08.12, 13:18 Citizens are evacuated from Vladikavkaz markets again

$6.08 .12,14: 44$ The regime of Contra-Terrorist Operation is repealed in Djeikhan Region of Ingushetia.

6.08.12, 15:38 Some people were killed after the explosion near blocking post in Grozny.

6.08.12, 16:40 Four servant-men were killed, other three were wounded after the terrorists' explosion in Grozny .

6.08.12, 17:30 Two supposed terrorists are looked for in the North Ossetia.

7.08.12, 09:47The burned body of policeman from Makhachkala was found in Kaspiisk.

7.08.12, 10:04 One fighter is killed in the suburb of Nalchik.

$7.08 .12,10: 20$ The group of fighters is blocked in a house in the suburb of Nalchik.

7.08.12, 10:50 Cadyrov suspects the Gakaev brothers in organizing act of terror in Grozny". (The News line from the portal Yuga.ru)

As we see on during only two days 6-7 of August 2012 only one news source has mentioned 9 negative news causes connected with armed confrontation and terrorism in 5 federal subjects of North the Caucasus region (North Ossetia, Ingushetia, Chechen Republic, Dagestan, Kabardino-Balkaria).

It is remarkable that such kind of negative news is never commented by the regional and federal authorities via mass media, except the cases when the authorities speak on the phenomenon of terrorism as a whole. Mass media inform on contra actions by the authorities, as we see in the citation.

\subsection{Discourse of the Authorities}

This type of discourse is formed and functions in mass media. The events that initiate such discourse are meetings and actions of the government institutions; statements of the governmental official at the federal and regional levels. These events acquire the direct broadcasting format, reporting format, direct address format and interview format. Such communicative events are aimed at presenting governmental position on the North Caucasus in general and on particular events or cases of public attention; at the defining the official frame of the phenomenon under discussion. Analysis has shown that the only news the authorities comment are conflicts that could be marked as having nationalistic causes. And the tendency of authorities discourse is to reject nationalistic version. In all cases incidents of such kind are commented by the office of public prosecutor or by the 
investigation departments of police. So, they lexically define incidents in the juridical terminology. In these juridical definitions such incidents are described as "of non-nationalistic character", "without nationalistic inspirations", "not on the nationalistic, but on private cause". In addition to such kind of definitions of the social realities the authorities try to oppose and even suppress news sources insisting nationalistic versions of negative news. In the news sources calling themselves 'independent' there is an opinion that the nationalistic issue in the North Caucasus is the "taboo" for the federal and regional authorities. Even the public statements of well-known persons from the region, for example, the Olympic champions, are oriented towards elimination of this opposition: "Caucasus-Russia". They mark they gained their gold medals "for the Motherland-the whole Russia-"from Kaliningrad to Vladivostok". (The report on TV. "ORT". 20.08.2012).

In the authorities discourse national-nationalistic-is preferable discussed in connection with foreign (US or European) examples.

"There (in the Western Europe) the immigrants are alien elements, while we all are the Mother-Russia's children",-Putin remarked. ((Putin in the Caucasus: assured that "it is not the "ballast"; but did not give trillions". 03.08.2011//NEWSru.com/14.09.2011).

Reports on big combat conflicts between police forces and separatist fighters were not commented by the first leaders of the state during two analyzed chronological periods.

The phenomenon of interdiscursivity can be determined while analysing reporting on the official event mentioned above-the meeting of the Government Committee on Social and Economic Development of the North-Caucasus Federal Region which was led by the Prime Minister V.V. Putin on 3 August 2011 in Kislovodsk.

Before this meeting V. Putin hold another meeting with the North Caucasus activists of the Youth Forum "Mashuk-2011". These two different events merged in the one in the numerous media reports. The formal factor of this amalgamation is the common agent-the figure of the Prime Minister. All media sources (Russian Information Agency "Novosti", RIA "Dagestan", "Vedomosti", News Agency Interfax, RBK, "Commersant", "Moskovsky Comsomolets", "Comsomolskaya Pravda" and others) published one news material on two events that proves their common meaning. Big number of media sources commented this news.

All news materials cited the Prime Minister in his definition of the North Caucasus and natives from the North Caucasus. He specially stressed the importance of the region because of its resources and strategic position: "The Caucasus is one of the pearls of Russia. Here we have very powerful human potential, very deep cultural layer". "...through the Caucasus we assure and uphold the important part of our geopolitical interests in this world's region". (NEWSru.com/03.08.2011).

The specific of the national character of natives from the North Caucasus was commented in a positive mode: "Highlanders, of cause, are the proud people,-Putin agreed,-but they are born not only to make war. They are very talented people... I remember from the student building practice [in the Soviet Union students worked on a building job during the summer vacation] that they are good builders," (NEWSru.com/03.08.2011). The topic "war" here is used as the negative opposition to the estimation and testimony given by the high authority of Vladimir Putin.

According to the statements of the federal authorities social and economic problems of the North Caucasus are the prior to many others. We can conclude this after observing following materials from one occasionally selected day's (19.06.2012) news line:

(Medvedev (Russian president at the time) named the development of the North Caucasus Federal Region the most important priority of the state" 19.06.12//http://www.yuga.ru/news/

(Medvedev demanded to do an extra work on the project of the state Program of the development of the North Caucasus Federal Region"19.06.12//http://www.yuga.ru/news/

The theme of the federal finance policy towards the North Caucasus Region can be found in this type of discourse as the continuation of the government's efforts to make stability in the region:

"The Ministry of Regional Development proposes 1.7 trillion rubles on the state program of the North Caucasus Federal Region development until 2025.” (yuga.ru19:04,19.06.12).

The theme of the financing the North Caucasus is common to the last analyzed discourse-the civic discourse. Here this subject transforms into the theme of extra-more than needed-financing of this region. Oppositional news sources even speculate on the theme that Kremlin pushing billions to the North Caucasus try to bribe the leaders of the regions. The federal authorities as a rule ignore this topic of the civic discourse. 


\subsection{The Civic Discourse}

Comments and discussions in the Internet communicative space in Russia in the analyzed period were free from the censorship and therefore had more independent character in comparison with materials in mass media. This is namely "civic" discourse for its actors interact with each other or with editorial stuff via Net and express their active personal position.

Research results show the main topics of this kind of discourse:

- Armed collisions between Federal forces and insurgents in the North Caucasus;

- Conflicts on the base of national contradictions with participation of people from the North Caucasus;

- Official federal policy on the North Caucasus;

- Extra financing of the North Caucasus republics.

The political opposition discourse interacts with the authorities' discourse in different forms. There are two strategies used by non-official independent actors. The first one plans to select the negative news and forms the line of this negative news flow very often without commentary on this line. The oppositional sources use only reliable information of the Russian information agencies. The site Kasparov.ru demonstrates such kind of communicative strategy. The big flow of every-day negative news is quite enough for the formation of critical position of the audience.

The second strategy is to form a counter-discourse opposing the discourse of the federal authorities by means of commenting the authorities' actions and statements and finding the contradictions in the official texts. This strategy of the counter-discourse purposes to disclose meanings hidden from the ordinary people. This strategy is illustrated by the publication on the site of vnssr.my1.ru"-The Renaissance of National-Social Justice Party. (vnssr.myl.ru).

The body of text is taken from the official site of Information agency "RBK" "V. Putin in the Caucasus: newcomers must respect the locals' traditions" (www/top.rbc.ru/04.08.2011). The counter-discourse is organized structurally as interchange of cited fragments and authorized fragments:

Fragment 1 (unchanged text from "RBK"): "On the meeting the Prime Minister declared that the future of Russia depends on consolidation of all nationalities and confessions' and remarked that newcomers must respect the locals' traditions".

Fragment 2(commentary): "Apparently, he said that to the Russians. This meeting produces an impression that Vladimir Vladimirovich is Caucasus-phyle and Russia-phob (who has the phobia to the Russians)".

Fragment 3 (again the text from "RBK"): "The Caucasus-is the special region of Russia. But nevertheless we have much in common: we have common Motherland, Homeland-Russia! It unites us. We have common roots, and more important-common future"-the press-office cites V. Putin".

Fragment 4 (Commentary): "What are the specifics of the Caucasus. The Russian Federation de facto lost war to Chechnya... De facto The Russian Federation pays contribution to Chechnya financing the budget of the Chechen Republic...” vnssr.my1.ru 14.09.2011.

It is interesting that followed text is loaned from the Information Agency "RBK" without comments. The comments done before in the first part of the text are enough for the transformation the modality of the publication. The strong critic commentary changes the mode of impression after the official information.

Very often the news of collisions and conflicts in the North Caucasus produce the numerous comments of the audience. Every next incident in the North Caucasus starts the next phase of the Internet discussion. All armed incidents are commented in terms of national policy and from geopolitical perspective. Political positions of the participants are often different but the modality of discussion and the frames are common: all the incidents are viewed as the sequences of unsolved problems in social sphere in the region, national mentality, and separatist tendencies of national elites of the North Caucasus. Main topics in this subtype of the civic discourse: abnormal conflict behavior of natives of the North Caucasus in the cities of the middle Russia, collisions between Russian youth and one from the Caucasus on nationalistic ground; various armed conflicts in the territory of the North Caucasus republics; extra financing the North Caucasus republics. The last topic is ironically defined as "the new Kremlin's strategy-to knock down Chechnya by luxury". The authors of comments on this theme are preoccupied with the fact that elites of these republics use enormous amount of federal finance for their own interests and not for the proclaimed goals of economic development and social welfare. These funds are used to the luxury consumption of regional politic elites, financing sport clubs (sometimes international or foreign). In 
comments on the celebration the Day of Grozny (capital of the Chechen Republic) and the birthday of the Chechen leader Ramzan Kadyrov a number of media sources described the character moment: "The leader of Chechnya Ramzan Kadyrov in his interview answering the question where are such big money on the celebration from, said: “Allah gives. Don't know. The money comes from somewhere". (Kasparov.ru/05.10.2011).

The research has shown that there are very few examples of the authorities' reaction on the discussions in the civic discourse. One of them: the reaction on the critics the federal financial policy towards the North Caucasus. Such critics increased in the mid of the autumn 2011. First official commentary appeared on TV format in the short variant. Being the President of Russia D. Medvedev said in his speech on TV: "It is speaking about the big wastes on the Caucasus. This is a nonsense ...[...] our problem is not in the money spend on the Caucasus, but in absence of the culture of the coexistence" . ((Night News)//ORT. 20.10.2011 23:30) Here the authorities discourse reinterprets the problem from the political one to the cultural one. It changes the frame of the discourse problem. This fact eliminates the opportunities to discuss the problem in political terms and shows the problem as depending on people's behavior.

Other official commentary on extra financing problem appeared only in December 2011: "The Prime Minister (V. Putin) notes the development of the Chechnya capital and thanks the leaders and people for their hard-working and industry". So, the positive features are highlighted from the beginning.

“...the Prime Minister hardly criticized those who appeal to stop finance the development of the North Caucasus. What does it mean to stop finance-it means not to invest in organization of the new working places. But then the young people from the North Caucasus will go to other place, first of all to the big cities...with the problems followed by this.-said Putin

What to do with them? Get them out? They will join gangs, organized crime,-said the Prime Minister." (infox.ru 20.12.2011) He appeals to mass media news lines full of terrorist incidents; he uses the frames of extraordinary preventive actions so to produce a fear and anxiety in the audience.

Analysis has shown that the discourses' interaction has temporal dimension. The authorities try make their answers on "hot" issues not simultaneously and not in direct media formats. They tend to use the frames of official actions. The format of such answers eliminates the very possibility of discussion or dialog. But in texts of statements there are data (such as definitions of the situation, estimations) loaned from the civic discourse. The hidden polemic between two types of discourses evidences the disagreement on the interpretation of social facts. The social actors define and reconstruct the same social problem in different ways.

\section{Conclusions}

The discourse of the federal authorities is the primer to the other types of discourse on the North Caucasus. Themes and subtopics from this discourse can be found in the mass media discourse (that is quite obvious) and in various kinds of the civic discourse politically marked and unmarked.

Negative news on the North Caucasus does not produce discussions in the media discourse. The federal authorities discourse also ignores such kind of information. But in the civic discourse news on the acts of violence produce the "wave" of hot discussions in the Internet. Analyzing the cases of interdiscourse between three types of discourse we fixed the presence of the phenomenon of the limited (stint) communicative interaction between the social actors.

The discourse of the authorities reacts on the themes in the civic discourse very seldom. The reaction can be put off in time. The lexical data in the media discourse and in the authorities discourse evidences an intention to discuss the North Caucasus problems in juridical terms (the mass media discourse) and cultural /value definitions (the authorities discourse). It is obvious in the instances of reformulating the discussed problems. While a political approach to these problems in the civic discourse prevails on cultural and juridical approaches. It proves the hypothesis, that actors use the different frames for the interpretation of social reality in this particular case.

In the civic discourse we found cases of counter-discourse strategy used to highlight the hidden meanings of the authorities' statements. The civic discourse demonstrates the highest interdiscursivity with the mass media and the authority discourses.

The character of comments in the civic discourse indicates that the discussed problem of the integration of the North Caucasus in Russian everyday reality is interpreted in public opinion as a problem of the federal authorities, but not the problem of the whole society.

As long as the federal authorities avoid speaking on this problem in dialog with the society and within the frames 
produced by the civic discourse, the problem will tend to stay unsolved. And the gap between two variants of interpretation of the social problem will grow.

This analysis shows that the communication strategy towards the integration of the North Caucasus region has to be corrected in order to be more effective. This correction has to be based, at least, on the principles listed below.

- The power institutions have to make steps to find the ways to use the common conceptual frames for the discussing problem of the North Caucasus' integration.

- The authorities' reaction on the current events in public discourse has to be more operative and less selective towards the type of the events.

- And the hardest task is to reinterpret the problem of the North Caucasus' integration from the legal and political frames to the social and cultural frames of the everyday life.

Resuming we'd like to highlight that by this study we propose methodology of critical discourse analysis for the evaluation the communicative strategies in order detect and to avoid the non-obvious but definitive mistakes of the communicative actors in complex situations of social interaction.

\section{Fundings}

This article received no specific grant from any funding agency in the public, commercial, or not-for-profit sectors.

\section{References}

Baker, P., Gabrielatos, C., KhosraviNik, M., Krzyzanowski, M., McEnery, T., \& Wodak, R. (2008). A useful methodological synergy? Combining critical discourse analysis and corpus linguistics to examine discourses of refugees and asylum seekers in the UK press. Discourse \& Society, 19(3), 273-306. http://dx.doi.org/10.1177/0957926508088962

Bednarek, M., \& Caple, H. (2012). News Discourse. Bloomsbury Academic (1st ed.).

Bednarek, M., \& Caple, H. (2014). Why do news values matter? Towards a new methodological framework for analyzing news discourse in Critical Discourse Analysis and beyond. Discourse \& Society, 135-158. http://dx.doi.org/10.1177/0957926513516041

Berezin, F. M., \& Tarasov, E. F. (Eds.). (1990). Speech influence in mass communications. Moscow: Nauka.

Bourdieu, P. (1980). Le sens practique. Les Editions de Vinuit, Paris.

Candlin, C., \& Maley, Y. (1997). Intertextuality and Interdiscursivity in the Discourse of Alternative Dispute Resolution. In B. Gunnarsson, P. Linell, \& B. Nordberg (Eds.), The Construction of Professional Discourse (pp. 201-222). London: Longman.

Champagne, P. (1990). Faire I'opinion le nouveau jeu politique. Paris: Minuit.

De Beaugrande, R. (2008). The Discourse and Counter-Discourse of Hugo Chavez. Critical Approaches to Discourse Analysis across Disciplines, 2(1), 17-30.

Glazkova, S. A. (2011). Critical discourse analysis as method to reconstruct the social problem. Problems of theoretical sociology, 8, 205-212. Saint-Petersburg: Skifia-Print.

Ivanov, O. I. (2008). The Social Problems: concepts and structure. Social Problems, 1, 7-19.

Jorgensen, M., \& Phillips, L. (2004). Discourse analysis as theory and method. SAGE Publications, 2002, L., Thousand Oaks, New Delhi.

Nazarov, M. M. (1991). The Political Consciousness: Characteristics and tendencies. Moscow.

Posel, I. (2008). Social problems: innovations and risks. Social Problems, 1, 111-127.

Reyes, A. (n. d.). Strategies of legitimization in political discourse: From words to actions. Discourse \& Society, 22, 781-807.

Titcher, S., Meyer, M., Wodak, R., \& Vetter, E. (2009). Methods of Text \& Discourse Analysis. SAGE Publications, 2000, L., Thousand Oaks, New Delhi.

Van Dijk, T. A. (1981). Studies in the Pragmatics of Discourse. In Context \& Cognition: Knowledge Frames and Speech Act Comprehension (pp. 215-244). The Hague: Monton Publishers. http://dx.doi.org/10.1515/978 3110826142

Van Dijk, T. A. (1985). Structures of News in the Press. In T. A. Van Dijk (Ed.), Discourse and Communication 
(pp.69-93). Berlin, N.Y. http://dx.doi.org/10.1515/9783110852141.69

Van Dijk, T. A. (1988). The Analysis of News as Discourse. In T. A. Van Dijk (Ed.), News Analysis. Case Studies of International and National News in the Press (pp. 1-30), Hillsdale, NJ: Erlbaum.

Van Dijk, T. A. (1993). Elite Discourse and Racism. Thousand Oaks, CA: SAGE. http://dx.doi.org/10.4135/97 81483326184

Van Dijk, T. A. (2005). Discourse and Racism in Spain and Latin America. Amsterdam: Benjamins. http://dx.doi. org/10.1075/dapsac.14

Wodak, R. (2004). Critical Discourse Analysis. In C. Seale, G. Gobo, J. F. Gubrium, \& D. Silverman (Eds.), Qualitative Research Practice (pp. 197-213). London: SAGE. http://dx.doi.org/10.4135/9781848608191. d17

Yasaveev, N. G. (2004). Constructing social problems in mass media. Kazan.

\section{Copyrights}

Copyright for this article is retained by the author(s), with first publication rights granted to the journal.

This is an open-access article distributed under the terms and conditions of the Creative Commons Attribution license (http://creativecommons.org/licenses/by/3.0/). 